\title{
Bee colony losses in Brazil: a 5-year online survey
}

\author{
Dayson Castilhos ${ }^{1}$, Genevile C. Bergamo ${ }^{2}$, Katia P. Gramacho ${ }^{1}$, \\ Lionel S. GONÇALVES ${ }^{1,3}$ \\ ${ }^{1}$ Departamento de Ciência Animal, Universidade Federal Rural do Semi-Árido, Av. Francisco Mota, 572, Mossoró, RN \\ CEP: 59625-900, Brazil \\ ${ }^{2}$ DCME - Universidade Federal Rural do Semi-Árido, Mossoró, RN, Brazil \\ ${ }^{3}$ FFCL - Universidade de São Paulo, Ribeirão Preto, SP, Brazil
}

Received 3 June 2018 - Revised 13 December 2018 - Accepted 7 March 2019

\begin{abstract}
In 2014, an online survey was launched to assess impacts of bee losses in Brazil (honeybees, stingless bees, and solitary bees). Events from January 2013 to December 2017 were collected on a website http://www. semabelhasemalimento.com.br/beealert as well as in apps for smartphones and tablets. In total, 322 post-confirmed qualified reports ( 287 for honeybee, 33 for stingless bee, 2 for solitary bee) were included in our analyses. Overall, 19,296 of 37,453 colonies and nests were lost (estimated $>1$ billion bees). Losses were highest for Africanized honeybees (Apis mellifera), followed by stingless bee Tetragonisca angustula. Honeybee $95 \%$ confidence intervals (CI) for loss rates on the basis of year, 5-year interval, regions, and operation sizes were estimated using a generalized linear model (GLM) for total loss $(T L)$ and a Wald method for average losses $(A L)$. Other species losses were mentioned in the text. Based on information from respondents, pesticide exposures were suspected as the main cause of nest and colony losses. In São Paulo State, which accounted for $45.7 \%$ of total reports, neonicotinoids and fipronil led pesticide are listed in 55.9\% of reports (fipronil, clothianidin, imidacloprid, and thiamethoxam are widely used in sugar cane plantations and orange groves in this state).
\end{abstract}

\section{bees / pesticides / neonicotinoids / fipronil / Apis mellifera / Tetragonisca angustula}

\section{INTRODUCTION}

Bee loss is a current large-scale problem affecting beekeeping, natural ecosystems, and farming systems, decreasing world populations of many bee species (Gill et al. 2012; Gonçalves 2012a, b; Neumann and Carreck 2010; Oldroyd 2007). Bees are regarded as the most efficient pollinators; therefore, this negative trend in pollinator populations, affecting several bee species in different ways,

Electronic supplementary material The online version of this article (https://doi.org/10.1007/s13592-019-00642-7) contains supplementary material, which is available to authorized users.

Corresponding author: D. Castilhos, dayson.castilhos@ufersa.edu.br

Manuscript editor: Cedric Alaux seems to be catastrophic for agricultural production, plant fertility, and biodiversity (Klein et al. 2007; (Breeze et al. 2011)). Notably, in recent years, honeybee colony losses (Apis mellifera) have been recorded all around the world with severe losses during winter in the USA and Europe ((Antúnez et al. 2017; Brodschneider et al. 2016; Chauzat et al. 2016); Jacques et al. 2017; Kulhanek et al. 2017; Oldroyd 2007; Stokstad 2007; vanEngelsdorp and Meixner 2010; van der Zee et al. 2012).

The current consensus is that a decline in bee species and other pollinators does not have a single cause, but it is multifactorial, including pesticides, habitat and environmental losses (resource decline), pathogen, and parasites (Decourtye et al. 2010; Kluser et al. 2010; Maini et al. 2010; Neumann and Carreck 2010). In addition to biotic and abiotic factors, declines in bee 
populations are also influenced by the value of products and services of these insects, taking into account human interests and activities (Aizen and Harder 2009; Maini et al. 2010).

In Brazil, honeybee colony losses (Apis mellifera) are usually attributed to intensive use of pesticides in agricultural areas (Silva et al. 2015, 2016; Cerqueira and Figueiredo 2017), followed by minor reports of Varroa destructor infestation, mismanagement, and starvation (Malaspina et al. 2008; Message 2010; Teixeira et al. 2011), although reports of queen failures are unusual.

To assess losses of several bee groups (honeybees, stingless bees, and solitary bees) in Brazil, Gonçalves (2014) launched an online survey (BEE ALERT) enabling beekeepers and others to report cases of bee losses. The application was linked to various websites, i.e., research institutes, reference laboratories, beekeeper associations, beekeeping magazines, and social and other related media, to increase exposure (van der Zee et al. 2013). The purpose of the current study was to quantify bee losses in Brazil between 2013 and 2017 and identify likely causes.

\section{MATERIALS AND METHODS}

Data acquisition was done through the BEE ALERT web survey, an application link to http://www.semabelhasemalimento.com. br/beealert, created by coordinators of the nongovernmental organization BEE OR NOT TO $\mathrm{BE}$. The objective was to record, in an online database, each occurrence of bee losses posted by national participants.

Respondents were those who voluntarily submitted details of bee losses. As visitors entered information into the survey in BEE ALERT, data were loaded into the website database, including size of losses, location, pollinator species, suggested causes, and types of flowering. Respondents remained anonymous.

We had reports on social bees: stingless bees (Tetragonisca angustula, Melipona subnitida, Melipona scutellaris, Melipona mandacaia, Melipona fasciculata, Tetragona clavipes, and Scaptotrigona postica) and Africanized honeybee (Apis mellifera) (Gonçalves 1974), which is a poly-hybrid of Apis mellifera scutellata, imported into Brazil by Kerr in 1956 (Kerr 1967; Ruttner 1975), and Apis mellifera mellifera and Apis mellifera ligustica, introduced by European immigrants (Gonçalves 1974; Kerr 1967; NogueiraNeto 1962). Solitary bee species were also reported: Xylocopa sp. and Centris sp.

As honeybee colonies were the most represented, their data were analyzed and presented in figures and tables, whereas data for stingless bees and solitary bees were simply mentioned in the text. Each report was considered a single occurrence. Increases or decreases in colonies due to deliberate commercial decisions during the interval were excluded from this study.

Sample size $(n)$ estimation followed a methodology suggested by van der Zee et al. (2013) in order to achieve statistical level of precision from the data collected, considering a percentage of $20 \%$ of natural colony losses, $5 \%$ estimation error, and a confidence level of $95 \%$, for an estimated national apiculture population of 350,000 beekeepers (CBA 2013; SEBRAE 2006), resulting in a minimum sample size of 246 reports.

To minimize false information, all data records were reconfirmed through contacts with respondents. A survey moderator verified cases with heavy colony, nest, or financial losses with visits to the sites and interviews with respondents for confirmation of the occurrence in loco, with photos and videos. Cases involving absence of losses, or incomplete, unconfirmed or untraceable questionnaires were excluded. During data collection, a macro-spreadsheet containing all variables from the web survey was edited, facilitating analysis of loss characteristics.

There are two ways to analyze colony losses. The first is total colony loss $(T L)$, which represents the overall rate of loss experienced by all participants. The second is average colony loss $(A L)$, which represents mean losses experienced by each participant (van der Zee et al. 2013; van Engelsdorp et al. 2011; vanEngelsdorp et al. 2013). Given a representative sample of operations, total and average loss rates are potentially biased. Total loss rate $(T L)$ is more influenced by large operations, whereas average loss rate $(A L)$ is more representative for all sizes of beekeeping operations (Daberkow et al. 2009). 
Comparisons were done based on both $T L$ and $A L$ (Daberkow et al. 2009). Honeybee data were analyzed on several bases: year and 5-year interval; region (Midwest, North-Northeast, Southeast and South); and operation size. According to Brazilian honeybee management standards (Apis mellifera), a small-size operation is 1 to 50 hives, medium-size operation is from 51 to 200 beehives, and large-size operation is $>200$ hives.

A generalized linear model (GLM) (McCullagh and Nelder 1989) with a quasi-binomial distribution and logit link (vanEngelsdorp et al. 2013) was used to estimate accurate confidence interval (CI) of total loss rate $(T L)$ and minimize effects due to differences in operation size. The Wald method was used to determine a confidence interval (CI) of average loss $(A L)$ rate. Statistical analyses were done with $\mathrm{R}$ software (R Development Core Team 2016), using a 5\% level of significance.

\section{RESULTS}

Since the BEE ALERT application was launched, 322 validated reports were uploaded (287 for honeybees, 33 for stingless bees, and 2 for solitary bees). Furthermore, 19 of 27 Brazilian states reported at least one occurrence of losses (either honeybees or native bees). All records were traced by satellite georeferencing (GPS) and indicated on a map (Figure 1). São Paulo State had the highest rate of occurrences $(45.7 \%$ of all reports), followed by Rio Grande do Sul (17.1\%), Minas Gerais (11.2\%), and Paraná (5\%).

Regarding activities related to bees, $78.6 \%$ were beekeepers in rural areas (honeybees), 9\% hobbyists (stingless beekeepers in urban perimeters), $5.9 \%$ stingless beekeepers (in rural areas), $5.3 \%$ both honeybee and stingless beekeepers in rural areas, and $1.2 \%$ researchers $(0.6 \%$ honeybee, $0.6 \%$ solitary bee) in university environments.

Regarding the occurrence of bee losses, the most affected months were January, March, June, August, November, and December, each with losses $\geq$ 9\%. In February, April, May, July, September, and October, losses ranged from 4.7 to $6.8 \%$ (Figure 2). There was no month without a loss.

Of 322 validated reports, $81.2 \%$ reported pesticides as the suspected cause of bee losses (bees found dead or agonal at hive entrance, on the ground, or failed to return to the colony or nest), $2.9 \%$ failures in management, $2.6 \%$ Varroa destructor, $2.3 \%$ municipal services combating mosquitos transmitting dengue (fogging), and $11 \%$ unable to specify a cause.

In this 5-year survey, there were 35,262 $(94.1 \%)$ honeybee, $2032(5.4 \%)$ stingless bee colonies, and $159(0.5 \%)$ solitary bee nests reported before losses $(t c)$. Regarding losses, 17,538 $(90.9 \%)$ honeybee, $1700(8.8 \%)$ stingless bee colonies, and $58(0.3 \%)$ solitary bee nests were reported $(t d)$. As honeybee reports $(n r)$ and losses $(t d)$ represent $90 \%$ of the survey, Table I shows the descriptive statistic of data separated by groups of bees, facilitating comparison to other honeybee studies.

As medians (Med) and means (Mean) from reported variables $t c$ and $t d$ were distinctly different, it was clear that these data were not normally distributed (Supplementary Material). Therefore, year and 5-year, regional and operation size loss rates were calculated with a $\mathrm{Z}$ distribution for $n r>60$ and with a $t$ distribution for $n r \leq$ 60 (vanEngelsdorp et al. 2013), for honeybee colony loss analyses only ( $n r=287$ reports). Stingless bee reports were separated, so readers can have a true idea of honeybee losses.

Total $(T L)$ and average $(A L)$ honeybee colony loss rates over the 5-year interval appeared similar (Table II).

Regional honeybee colony losses were different; however, overlaps of confidence intervals suggested non-significant statistical differences among losses (Table III). The highest rate of average colony loss $(A L)$ in Brazil was in the South region (67.6\%), followed by the Southeast region (63.5\%).

To improve understanding of total loss (TL) and average loss $(A L)$ rates (honeybees only) (Daberkow et al. 2009), reports were categorized by operation size (Table IV). Small-size units (150 hives) contributed $61.3 \%$ of reports, but only accounted for $11 \%$ of operations. Medium-size units (51-200 hives) contributed $25.8 \%$ of reports and accounted for $24.9 \%$ of operations, and largesize units ( $>200$ hives) contributed $12.9 \%$ of reports and accounted for $64.1 \%$ of operations.

According to survey participants, medium- and large-size beekeeping operations are considered 


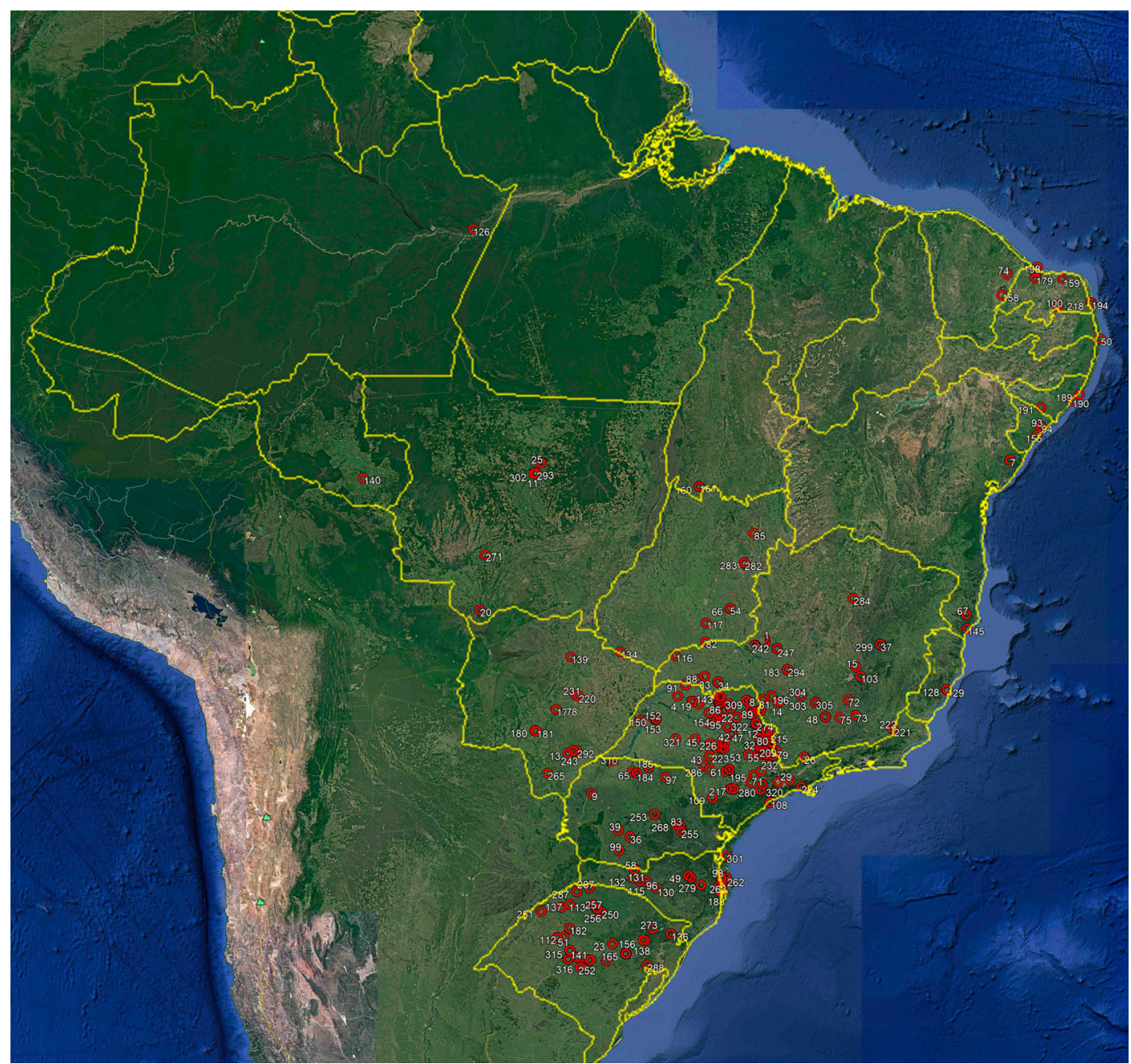

Yellow line $=$ national and state borders.

Source: Cartographic base: GOOGLE EARTH, 2017 modified by author with survey data.

Figure 1 GPS distribution of surveyed bee losses in Brazil. Yellow line = national and state borders. Source: Cartographic base: GOOGLE EARTH 2017, modified by author with survey data.

their main economic activity. Small- and mediumsize beekeepers had similar average losses, whereas large-size beekeepers incurred lesser average losses.

\section{DISCUSSION}

As a result of the first long-term survey of bee losses in Brazil, many expected responses were

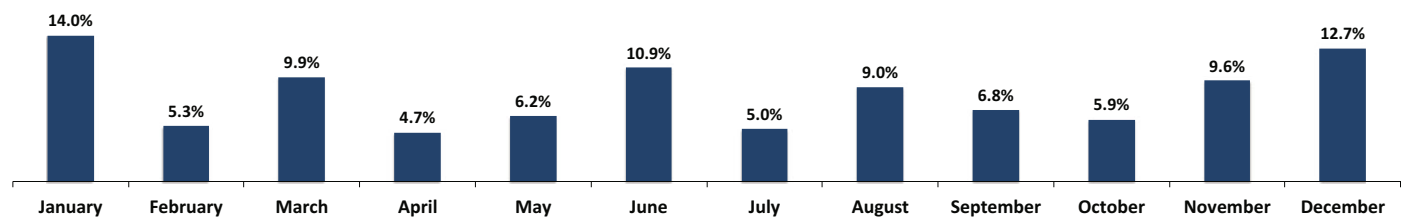

Figure 2 Percent monthly bee loss, averaged from 2013 to 2017. 
Table I. Descriptive statistic for the number of colonies before losses $(t c)$ and lost colonies $(t d)$ grouped by species of bees

\begin{tabular}{|c|c|c|c|c|c|c|c|c|}
\hline Group & $n r$ & Species & & $n$ & Mean & $95 \% \mathrm{CI}$ & Med & $\begin{array}{l}\text { Interquartile } \\
\text { range }\end{array}$ \\
\hline \multirow[t]{2}{*}{ Honeybee } & 287 & Apis mellifera & $\begin{array}{c}\text { Before } \\
\text { losses }\end{array}$ & 35,262 & 122.9 & $93.2-152.5$ & 33 & $19-120$ \\
\hline & & & $\begin{array}{l}\text { Lost } \\
\text { colonies }\end{array}$ & 17,538 & 61.1 & $48.1-74.1$ & 25 & $8-70$ \\
\hline \multirow[t]{14}{*}{$\begin{array}{l}\text { Stingless } \\
\text { bee }\end{array}$} & 17 & Tetragoniscaangustula & $\begin{array}{c}\text { Before } \\
\text { losses }\end{array}$ & 1799 & 105.8 & $\begin{array}{r}-79.1- \\
290.7\end{array}$ & 14 & $6-33$ \\
\hline & & & $\begin{array}{l}\text { Lost } \\
\text { colonies }\end{array}$ & 1572 & 92.5 & $\begin{array}{r}-94.0- \\
279.0\end{array}$ & 3 & $2-6.5$ \\
\hline & 5 & Scaptotrigona postica & $\begin{array}{c}\text { Before } \\
\text { losses }\end{array}$ & 37 & 7.4 & $-2.4-17.2$ & 4 & $1-15.5$ \\
\hline & & & $\begin{array}{l}\text { Lost } \\
\text { colonies }\end{array}$ & 33 & 6.6 & $-3.2-16.4$ & 2 & $1-14.5$ \\
\hline & 3 & Melipona mandacaia & $\begin{array}{c}\text { Before } \\
\text { losses }\end{array}$ & 63 & 21.0 & $\begin{array}{r}-62.9- \\
104.9\end{array}$ & 2 & $1-60$ \\
\hline & & & $\begin{array}{l}\text { Lost } \\
\text { colonies }\end{array}$ & 16 & 5.3 & $-11.2-21.9$ & 2 & $1-13$ \\
\hline & 3 & Melipona scutellaris & $\begin{array}{c}\text { Before } \\
\text { losses }\end{array}$ & 35 & 11.7 & $4.5-18.8$ & 10 & $10-15$ \\
\hline & & & $\begin{array}{l}\text { Lost } \\
\text { colonies }\end{array}$ & 13 & 4.3 & $-4.4-13.1$ & 4 & $1-8$ \\
\hline & 1 & Melipona fasciculata & $\begin{array}{c}\text { Before } \\
\text { losses }\end{array}$ & 50 & - & - & - & - \\
\hline & & & $\begin{array}{l}\text { Lost } \\
\text { colonies }\end{array}$ & 30 & - & - & - & - \\
\hline & 2 & Melipona subnitida & $\begin{array}{c}\text { Before } \\
\text { losses }\end{array}$ & 16 & 8.0 & - & 8 & - \\
\hline & & & $\begin{array}{l}\text { Lost } \\
\text { colonies }\end{array}$ & 6 & 3.0 & - & 3 & - \\
\hline & 2 & Tetragona clavipes & $\begin{array}{c}\text { Before } \\
\text { losses }\end{array}$ & 32 & 16.0 & - & 16 & - \\
\hline & & & $\begin{array}{l}\text { Lost } \\
\text { colonies }\end{array}$ & 30 & 15.0 & - & 15 & - \\
\hline \multirow[t]{4}{*}{$\begin{array}{l}\text { Solitary } \\
\text { bee }\end{array}$} & 1 & Xylocopa sp. & $\begin{array}{c}\text { Before } \\
\text { losses }\end{array}$ & 100 & - & - & - & - \\
\hline & & & Lost nests & 38 & - & - & - & - \\
\hline & 1 & Centris sp. & $\begin{array}{c}\text { Before } \\
\text { losses }\end{array}$ & 59 & - & - & - & - \\
\hline & & & Lost nests & 20 & - & - & - & - \\
\hline \multirow[t]{2}{*}{ Total } & 322 & & $\begin{array}{c}\text { Before } \\
\text { losses }\end{array}$ & 37,453 & 116.3 & $81.7-143.8$ & 30 & $14.5-87.5$ \\
\hline & & & Lost & 19,296 & 59.9 & $40.9-76.8$ & 20 & $6.0-54.5$ \\
\hline
\end{tabular}

$n r$, number of reports; $n$, number of colonies; Mean, average number of colonies per report; Med, median number of colonies per report; $95 \% \mathrm{CI}$, confidence interval

confirmed. It is noteworthy that these numbers represented only losses recorded in BEE ALERT application. In addition, presumably many beekeepers failed to report losses, fearing they could be forced to remove their apiaries from farms where they borrow or rent space for honey production. 
Table II. Year and 5-year interval total and average honeybee (Apis mellifera) colony loss rates.

\begin{tabular}{lccccc}
\hline \multicolumn{1}{c}{ Year } & $n r$ & $T L_{(\%)}$ & $95 \% \mathrm{CI}_{(\mathrm{glm})}$ & $A L_{(\%)}$ & $95 \% \mathrm{CI}_{\text {(Wald) }}$ \\
\hline 2013 & 22 & 50.4 & $39.5-61.4$ & 54.9 & $39.3-70.6$ \\
2014 & 77 & 49.3 & $42.6-55.9$ & 61.5 & $54.1-69.0$ \\
2015 & 48 & 54.6 & $44.8-64.3$ & 70.5 & $60.2-80.9$ \\
2016 & 74 & 45.8 & $39.9-51.7$ & 62.6 & $56.0-69.3$ \\
2017 & 66 & 49.7 & $42.4-57.0$ & 69.7 & $62.3-77.0$ \\
$2013-2017$ & 287 & 49.7 & $46.3-53.2$ & 64.7 & $61.0-68.4$ \\
\hline
\end{tabular}

$n r$, number of reports; $T L_{(\%)}$, total loss; $A L_{(\%)}$, average loss; $95 \% C I$, confidence interval

Annual colony loss rates were expected to be high, ranging from $50 \%$ or higher (Cerqueira and Figueiredo 2017; Silva et al. 2015, 2016). Based on an average estimated population of 60,000 Apis mellifera bees per colony, more than one billion honeybees were estimated to have died, causing potential reductions in pollination and biodiversity, and large financial losses.

Considering only honeybee colonies reported dead or empty, this 5-year approach indicates trends. Annually, average loss rates $(A L)$ ranged from 54.9 to $70.5 \%$ and total loss rates $(T L)$ from 49.3 to $54.6 \%$. In contrast, in Uruguay, there was an annual $28.6 \%$ average loss and $28.5 \%$ total loss (Antúnez et al. 2017). In South Africa, an average loss of $20.6 \%$ and total loss of $29.6 \%$ were estimated for 2009, and an average loss of $28.6 \%$ and total loss of $46.2 \%$ for 2010 (Pirk et al. 2014). In the USA, estimated annual average loss reached $44.2 \%$ and total loss was $40.5 \%$ in $2015 / 2016$ (Kulhanek et al. 2017), and annual average loss was $49.4 \%$ and total loss was $45.2 \%$ in $2012 / 2013$ (Steinhauer et al. 2014). In Europe, annual losses are not commonly estimated, but in 29 European countries, during the winter of $2015 / 2016$, there was an estimated overall loss rate of $12 \%$ with a range of 6.4 to $29.5 \%$ among countries (Brodschneider et al. 2016). In yet another study based on field inspections in 17 European countries, estimated winter losses ranged from 4.7 to $30.6 \%$ (Chauzat et al. 2016), whereas in a similar study the following year, estimated losses ranged from 2 to $32 \%$ (Jacques et al. 2017).

Given these apparent differences among countries, years, and seasons, we inferred that colony losses were strongly related to environment, climate, bee species, and beekeeping practices. Although Brazilian losses seemed higher than other countries, reproduction and capture of new colonies can be accomplished within one season, making it possible to totally or at least partially recover from losses (van Engelsdorp et al. 2011), as the Africanized honeybee is well adapted to tropical environments. However, reproduction of colonies to repopulate empty hives has inherent costs for beekeepers and stingless beekeepers.

Table III. Total and average honeybee (Apis mellifera) colony loss rates by region.

\begin{tabular}{lrcccc}
\hline \multicolumn{1}{c}{ Region } & $n r$ & $T L_{(\%)}$ & $95 \% \mathrm{CI}_{(\mathrm{glm})}$ & $A L_{(\%)}$ & $95 \% \mathrm{CI}_{(\text {Wald }}$ \\
\hline Midwest & 22 & 63.2 & $48.9-76.1$ & 56.5 & $41.9-71.1$ \\
North/Northeast & 21 & 55.0 & $41.7-67.9$ & 54.5 & $39.9-69.1$ \\
Southeast & 164 & 50.3 & $45.6-55.0$ & 63.5 & $60.7-70.9$ \\
South & 80 & 45.5 & $39.7-51.3$ & 67.6 & $60.8-73.7$ \\
Total & 287 & 49.7 & $46.3-53.2$ & 64.7 & $61.0-68.4$ \\
\hline
\end{tabular}

$n r$, number of reports; $T L_{(\%)}$, total loss; $A L_{(\%)}$, average loss; $95 \% C I$, confidence interval 
Table IV. Total and average honeybee (Apis mellifera) colony loss rates by operation size

\begin{tabular}{lrrrrrrr}
\hline Op. size & \multicolumn{1}{c}{$n r$} & \multicolumn{1}{c}{$t c$} & \multicolumn{1}{c}{$t d$} & $T L_{(\%)}$ & $95 \% \mathrm{CI}_{(\mathrm{glm})}$ & $A L_{(\%)}$ & $95 \% \mathrm{CI}_{\text {(Wald) }}$ \\
\hline $1-50$ & 176 & 3888 & 2686 & 69.1 & $64.2-73.7$ & 68.0 & $63.2-72.8$ \\
$51-200$ & 74 & 8782 & 5848 & 66.6 & $59.6-73.1$ & 67.7 & $60.9-74.5$ \\
$>200$ & 37 & 22,592 & 9004 & 39.9 & $32.1-47.9$ & 42.9 & $33.5-52.4$ \\
Total & 287 & 35,262 & 17,538 & 49.7 & $46.3-53.2$ & 64.7 & $61.0-68.4$ \\
\hline
\end{tabular}

$n r$, number of reports; $t c$, number of colonies reported before losses; $t d$, number of lost colonies; $T L_{(\%)}$, total loss; $A L_{(\%)}$, average loss; $95 \% C I$, confidence interval

Varroa destructor is not a big problem in Brazil, particularly in tropical regions. Moretto et al. (1991) suggested that climate type (warm temperatures and no winters) and hybridization (behavioral defense against Varroa ) have a positive effect on mite reduction and mean infestation rates were $5 \%$. Nine studies on mite infestation were presented in the 22nd CONBRAPI-Brazilian Beekeeping Congress, 2018, and mean infestation rates in four of five regions were 5\% ((Bridi et al. 2018); Estevan et al. 2018; Freire et al. 2018; Gomes et al. 2018; Pereira et al. 2018; Pinho et al. 2018; Sambrana and dos Reis 2018; Silva et al. 2018; Vinhal-Silva et al. 2018). Despite the long (27 years) interval between the initial and recent publications, we concluded that there was no evidence that Varroa destructor infestation had increased nationwide.

Based on beekeepers responses and environmental knowledge (aerial or mechanical spraying observed before losses; bees found dead or agonal at the hive entrance, on the ground, or simply failed return to the colony; dead bees with outstretched legs, wings, and proboscis), pesticide exposures were speculated to be the main cause of colony losses, consistent with Brazil being the world's biggest consumer of pesticides (Bombardi 2017; dos Santos et al. 2018; INCA 2015). Fipronil was the most frequently mentioned pesticide, followed by the neonicotinoid insecticides imidacloprid, thiamethoxam, and clothianidin. Various agricultural crops, including sugar cane, oranges, and other tropical fruits, are commonly produced in areas with highest rates of bee deaths and collapses. Losses were greatest for honeybee (Apis mellifera) and stingless bee jatai (Tetragonisca angustula). In the State of Paraná alone, the loss of 1508
Tetragonisca angustula nests were attributed to pesticides, based on input from stingless beekeepers and in loco author's visits to confirm colony losses.

It was noteworthy that the highest incidence of losses coincided with months when agricultural procedures would be underway, giving more credence to the apparent association between losses and agricultural activities.

Colony losses by region were not statistically different. However, there were differences on the basis of operation size, as large-size beekeepers incurred lower total and average loss rates, consistent with previous publications ((Brodschneider et al. 2016); van Engelsdorp et al. 2011; vanEngelsdorp et al. 2013). This could be due to large-size beekeepers having better equipment and facilities and more standardized management procedures. For small-size beekeepers, loss of even a few colonies could be devastating and preclude recovery.

In conclusion, according to respondents, pesticides were suspected as the main cause of the high bee loss rates in Brazil and they are proposed as the main cause of pollinator decline (dos Santos et al. 2018). Annual losses were estimated around $50 \%$, with an estimate that more than one billion bees died, without taking into account bee losses in the wild.

\section{ACKNOWLEDGEMENTS}

Authors thank the BEE OR NOT TO BE for access to their database, UFERSA for resources and facilities, EVA CRANE TRUST for funding, Nathalie Steinhauer for GLM support, John Kastelic for manuscript editing, and all respondents for participating. 


\section{AUTHORS' CONTRIBUTIONS}

LSG created the website and questionnaire. GCB performed the R statistical analyses. KPG managed the project and resources. DC collected the data, visited the respondents, and structured the variables. All authors participated in paper writing.

\section{COMPLIANCE WITH ETHICAL STANDARDS}

Conflict of interest The authors declare that they have no conflict of interest.

\section{Pertes de colonies d'abeilles au Brésil: une enquête quinquennale en ligne}

abeilles / pesticides / néonicotinoüdes / fipronil / Apis mellifera / Tetragonisca angustula

Verluste an Bienenvölkern in Brasilien: eine FünfJahresübersicht

Bienen / Pestizide / Neonicotinoide / Fipronil / Apis mellifera / Tetragonisca angustula

\section{REFERENCES}

Aizen, M.A., Harder, L.D. (2009) The global stock of domesticated honeybees is growing slower than agricultural demand for pollination. J. Cur. Biol. 19 (11), 915-918. DOI:https://doi.org/10.1016/j. cub.2009.03.071.

Antúnez, K., Invernizzi, C., Mendoza, Y., vanEngelsdorp, D., Zunino, P. (2017) Honeybee colony losses in Uruguay during 2013-2014. Apidologie, 48 (3), 364-370. DOI:https://doi.org/10.1007/s13592-0160482-2.

Bombardi, L.M. (2017) Geografia do Uso de Agrotóxicos no Brasil e Conexões com a União Europeia. FFLCHUSP.

Breeze, T.D., Bailey, A.P., Balcombe, K. G., Potts, S. G. (2011) Pollination services in the UK: how important are honeybees? Agric., Eco. \& Environ. 142 (3-4), 137-143. DOI:https://doi.org/10.1016/j. agee.2011.03.020.

Bridi, T.R., Polesso, A.M., Abreu, L., Bogus, G.M., Borsuk, L.C. (2018) Incidência de Varroa destructor e Aethina tumida em colmeias de Apis mellifera na região oeste de Santa Catarina, in: Anais do Congresso Brasileiro de Apicultura, 22... CBA, Joinville, SC, p.
211. Available at: http://www.conbrapi2018.com.br. Accessed 16 July 2018.

Brodschneider, R., Gray, A., Zee, R.V.D., Adjlane, N., Brusbardis, V., et al. (2016) Preliminary analysis of loss rates of honeybee colonies during winter 2015/16 from the COLOSS survey. J. Apic. Res. 55 (5), 375 378 . DOI: https://doi.org/10.1080 /00218839.2016.1260240.

CBA - Confederação Brasileira de Apicultura e Meliponicultura. (2013) Audiência Pública - Câmara dos Deputados. Mortandade Disseminada de Abelhas devido ao uso de agrotóxicos. Brasília, DF. Available at: http://www.agricultura.gov.br/arq_ editor/file/camaras_setoriais/Mel_e_produtos_ apicolas/21RO/App_CBA.pdf. Accessed 14 Mar 2015.

Cerqueira, A., Figueiredo, R.A. (2017) Percepção ambiental de apicultores: desafios do atual cenário apícola no interior de São Paulo. Acta Brasiliensis, 1, 17-21. DOI:https://doi.org/10.22571/actabra3201754.

Chauzat, M.P., Bougeard, S., Hendrikx, P., RibièreChabert, M. (2016) Risk indicators affecting honeybee colony survival in Europe: one year of surveillance. Apidologie, 47 (3), 348-378. DOI:https://doi. org/10.1007/s13592-016-0440-z.

Daberkow, S., Korb, P., Hoff, F. (2009) Structure of the U.S. beekeeping industry: 1982-2002 J. Econ. Ent. 103 (3), 868-886. DOI:https://doi.org/10.16013 /029.102.0304.

Decourtye, A., Mader, E., Desneux, N. (2010) Landscape enhancement of floral resources for honeybees in agroecosystems. Apidologie, 41 (3), 264-277. DOI:https://doi.org/10.1051/apido/2010024.

dos Santos, C.F., Otesbelgue, A., Blochtein, B. (2018) The dilemma of agricultural pollination in Brazil: beekeeping growth and insecticide use. PloS ONE, 13 (7), e0200286. DOI: https://doi.org/10.1371/journal. pone. 0200286 .

Estevan, S., Abreu, L., Bogus, G.M., Borsuk, L.C. (2018) Ocorrencia de Varroa destructor e Aethina tumida em colmeias de Apis mellifera no município de Trindade do Sul, RS, in: Anais do Congresso Brasileiro de Apicultura, 22 ... CBA, Joinville, SC, p. 207. Available at: http://www.conbrapi2018.com.br. Accessed 16 July 2018.

Freire, D.S., Costa, P.S.C., Santos, A.B. (2018) Avaliação do índice de infestação pelo ácaro Varroa destructor em colônias do apiário da Universidade Estadual do Sudoeste da Bahia, campus Vitória da Conquista-BA, in: Anais do Congresso Brasileiro de Apicultura, 22... CBA, Joinville, SC, p. 202. Available at: http://www. conbrapi2018.com.br. Accessed 16 July 2018.

Gill, R.J., Ramos-Rodrigues, O., Raine, N.E. (2012) Combined pesticide exposure severely affects individualand colony-level traits in bees. Nature, 491 (7422), 105-108. DOI: https://doi.org/10.1038/nature11585.

Gomes R.V.R.C., Albuquerque, J.G.S.S., Santana, S.S., Souza, D.T.M., Gramacho, K.P. (2018) Nível de infestação com varroa em colônias de abelhas africanizadas em área canavieira. In: Anais do 
Congresso Brasileiro de Apicultura, 22... CBA, Joinville, SC, p. 204. Available at: http://www. conbrapi2018.com.br. Accessed 16 July 2018.

Gonçalves, L.S. (1974) The introduction of the African bees (Apis mellifera adansonii) into Brazil and some comments on their spread in South America. Am. Bee J., 11 (114), pp. 414-415, 419.

Gonçalves, L.S. (2012a) O Desaparecimento das abelhas, suas causas, consequências e o risco dos Neonicotinóides para o Agronegócio. Mensagem Doce, 117, 2-12. Available at: http://www.apacame. org.br/mensagemdoce/117/artigo1.htm.

Gonçalves, L.S. (2012b) Consequências do Desaparecimento (CCD) das Abelhas no Agronegócio Apícola Internacional e em especial no Brasil. In: Anais do Encontro sobre Abelhas de Ribeirão Preto, 10. (CD-ROM), pp. 24-25.

Gonçalves, L.S. (2014) O uso dos pesticidas sistêmicos no combate às pragas e seus reflexos nas abelhas: campanha de proteção às abelhas e o aplicativo Bee Alert. In: Libro de Resúmenes del XI Congreso Latinoamericano de Apicultura, 2014-FILAPI. Puerto Iguazu-Misiones, Argentina, 03 a 06 de setembro 2014, p.15.

GOOGLE EARTH. (2017) Geo-locatorSoftware, version: 7.1.7.2602. Available at: https://www.google.com. br/earth/download/ge/agree.html. Accessed 10 Jul 2017.

INCA - Instituto Nacional de Combate ao Câncer. (2015) Posicionamento do Instituto Nacional de Câncer José de Alencar Gomes da Silva acerca dos agrotóxicos. Available at: http://www 1.inca.gov. br/inca/Arquivos/comunicacao/posicionamento_do inca_sobre_os_agrotoxicos_06_abr_15.pdf. Accessed $15 \overline{\mathrm{Dec}} 20 \overline{17}$.

Jacques, A., Laurent, M., EPILOBEE Consortium, RibièreChabert, M., Saussac, M., Bougeard, S., et al. (2017) A pan-European epidemiological study reveals honeybee colony survival depends on beekeeper education and disease control. PLoS ONE 12 (3), e0172591. https://doi.org/10.1371/journal.pone.0172591.

Kerr, W.E. (1967) The history of the introduction of African bees to Brazil. S. Afr. Bee J. 39, (2), pp. 3-5.

Klein, A-M., Vaissière, B.E., Cane, J.E., Steffan-Dewenter, I., Cunningham, S.A., Kremen, C., Tscharntke, T. (2007) Importance of pollinators in changing landscapes for world crops. Proc. R. Soc. B, 274 (1608), 303-313. DOI:https://doi.org/10.1098 /rspb.2006.3721.

Kluser, S., Neumann, P., Chauzat, M-P., Pettis, J.S. (2010) Global honeybee colony disorder and other threats to insect pollinators. Available at: http://www.unep. org/archive-ouverte.uni ge.ch/unige:32251. Accessed 20 Jan 2016.

Kulhanek, K., Steinhauer, N., Rennich, K., Caron, D.M., Sagili, R.R., et al. (2017) A national survey of managed honey bee 2015-2016 annual colony losses in the USA. J. Apic. Res. 56 (4), 328-340. DOI:https://doi. org/10.1080/00218839.2017.1344496.

Maini, S., Medrzycki, P., Porrini, C. (2010) The puzzle of honeybee losses: a brief review. Bull. Insectol. 63 (1),
153-160. Available at: http://www.bulletinofinsectology. org/pdfarticles/vol63-2010-153-160maini.pdf. Accessed 15 Mar 2015.

Malaspina, O., Souza, T.F., Zacarin, E.C.M.S., Cruz, A.S., De Jesus, D. (2008) Efeitos provocados por agrotóxicos em abelhas no Brasil. In: Anais do Encontro Sobre Abelhas, 8. Anais eletrônicos... Ribeirão Preto, pp. 41-48. Available at: http://www. academia.edu/893657/Olfactory_Information_Use and_Guidance_of_Nestmates_To_Food_in_Stingless ${ }^{-}$Bees. Accesse $\bar{d} 06$ Oct $20 \overline{15}$.

McCullagh, P., Nelder J.A. (1989) Generalized Linear Models. $2^{\text {nd }}$ ed, in: Chapman, Hall. Monographs on Statistics and Applied Probability, 37. Springer, US. DOI:https://doi.org/10.1007/978-1-4899-3242-6.

Message, D. (2010) Principais problemas sanitários em apiários do Brasil. CCD (Colony Collapse Disorder) ou desaparecimento das abelhas, in: Congresso Iberolatinoamericano de Apicultura, 10. Natal. Anais... CD-ROM.

Moretto, G., Gonçalves, L.S., De Jong, D., Bichuette, M.Z. (1991) The effects of climate and bee race on Varroa jacobsoni Oud infestations in Brazil. Apidologie, 22 (3), 197-203. DOI:https://doi.org/10.1051 /apido:19910303.

Neumann, P., Carreck, N.L. (2010) Honeybee colony losses. J. Apic. Res. 49 (1), 1-6. DOI:https://doi. org/10.3896/IBRA.1.49.1.01.

Nogueira-Neto, P. (1962) Início da Apicultura no Brasil, in: Boletim de Agricultura. Secretaria de Agricultura do Estado de São Paulo, SP, pp. 5-14.

Oldroyd, B.P. (2007) What's killing American honeybees? PLoS Biol., 5 (6), e168, 1195-1199. DOI:https://doi. org/10.1371/journal.pbio.0050168.g001.

Pereira, E., Arboitte, M.Z., Anastácio, M.A., Ribeiro, T.B., Sonego, J.V.W. (2018) Eficiência de metodologias para determinação de índices de varroa, in: Anais do Congresso Brasileiro de Apicultura, 22... CBA, Joinville, SC, p. 208. Available at: http://www. conbrapi2018.com.br. Accessed 16 July 2018.

Pinho, V.R., Silva, S.B.A., Ribeiro, L.S., Samel-Rocha, J., Souza, D.C. (2018) Incidência do ácaro Varroa destructor associada a dietas em colônias de Apis mellifera, in: Anais do Congresso Brasileiro de Apicultura, 22 ... CBA, Joinville, SC, p. 212. Available at: http://www.conbrapi2018.com.br. Accessed 16 July 2018.

Pirk, C.W.W., Human, H., Crewe, R.M., vanEngelsdorp, D. (2014) A survey of managed honey bee colony losses in the Republic of South Africa - 2009 to 2011. J. Apic. Res., 53 (1), 35-42. DOI: https://doi.org/10.3896 /IBRA.1.53.1.03.

R Development Core Team. (2016) R version 3.3.1: A language and environment for statistical computing. Vienna: R Foundation for Statistical Computing. Available at: http://www.r-project.org. Accessed 20 Dec 2016.

Ruttner, F. (1975) Honeybee races in Africa, in: International Apiculture Congress, 26, Grenoble, France: Apimondia. p. 347-366. 
Sambrana, I.R., dos Reis, V.D.A. (2018) Infestação pelo ácaro Varroa destructor em pré-pupas e pupas de Apis mellifera em Ladário-MS: 2016-2017, in: Anais do Congresso Brasileiro de Apicultura, 22... CBA, Joinville, SC, p. 205. Available at: http://www. conbrapi2018.com.br. Accessed 16 July 2018.

SEBRAE - Serviço Brasileiro de Apoio às Micro e Pequenas Empresas. (2006) Desafios da Apicultura Brasileira. Revista Sebrae Agronegócios, 3, 5. Available at: https://issuu.com/planomidia/docs/rev_ agronegocio3. Accessed 15 Mar 2015.

Silva, I.P., Oliveira, F.A.S., Pedroza, H.P., Gadelha, I.C.N., Melo, M.M., Soto-Blanco, B. (2015) Pesticide exposure of honeybees (Apis mellifera) pollinating melon crops. Apidologie, 46, 703-715. DOI: https://doi. org/10.1007/s13592-015-0360-3.

Silva, I.P., Melo, M.M., Soto-Blanco, B. (2016) Efeitos tóxicos dos praguicidas para abe- lhas. Rev. Bras. Hig. San. Anim. 10 (1), 142-157. DOI: https://doi. org/10.5935/1981-2965.20160013.

Silva, H.M., Guimarães-Beelen, P., Beelen, R. (2018) Índices de infestação do ácaro Varroa destructor em colônias de abelhas Apis mellifera na Zona da Mata de Alagoas, in: Anais do Congresso Brasileiro de Apicultura, 22 ... CBA, Joinville, SC, p. 214. Available at: http://www.conbrapi2018.com.br. Accessed 16 July 2018.

Steinhauer, N.A., Rennich, K., Wilson, M.E., Caron, D.M., Lengerich, E.J., et al. (2014) A national survey of managed honey bee 2012-2013 annual colony losses in the USA: results from Bee Informed Partnership. J. Apic. Res. 53 (1), 1-18. DOI: https://doi.org/10.3896 /IBRA.1.53.1.01.

Stokstad, E. (2007) Entomology: the case of the empty hives. Science, 316, 970-972. DOI:https://doi. org/10.1126/science.316.5827.970.

Teixeira, E.W., Message, D., Alves, M.L., Santos, L.G., Simões, Z.L.P. Guidugli-Lazzarini, K.R., Bitondi, M.M.G., Lourenço, A.P., Silva, I.C., Chen, Y., Evans, J.D., Pettis, J.P. (2011) Honeybee health and losses in Brazil. Rev. Educ. Cont. Med. Vet. e Zootec. 9 (3), 55. Available at: http://revistas.bvsvet.org.br/recmvz/article/view/73/58. Accessed 28 Feb 2016. van der Zee, R., Pisa, L., Andonov, S., Brodschneider, R., Charrière, J-D., et al. (2012) Managed honeybee colony losses in Canada, China, Europe, Israel and Turkey, for the winters of 2008-2009 and 2009-2010. J. Apic. Res. 51 (1), 100-114. DOI:https://doi.org/10.3896 /ibra.1.51.1.12.

van der Zee, R., Gray, A., Holzmann, C., Pisa, L., Brodschneider, R., et al. (2013) Standard survey methods for estimating colony losses and explanatory risk factors in Apis mellifera, in: Dietemann, V., Ellis, J.D., Neumann, P. (Eds.) The COLOSS BEEBOOK, Volume II: Standard methods for Apis mellifera research. J. Apic. Res. 52 (4), 1-35. DOI:https://doi. org/10.3896/ibra.1.52.4.18.

van Engelsdorp, D., Brodschneider, R., Brostaux, Y., van der Zee, R., Pisa, L., et al. (2011) Calculating and reporting managed honey bee colony losses, in: Sammataro, D., Yoder, J.A. (Eds.) Honey bee colony health: challenges and sustainable solutions. CRC Press, Taylor \& Francis Group, Boca Raton, FL, pp. 237-244. DOI: https://doi.org/10.1201/b111318-21.

vanEngelsdorp, D., Meixner, M.D. (2010) A historical review of managed honeybee populations in Europe and the United States and the factors that may affect them. J. Invert. Pathol. 103 (Supplement), S80-S95. DOI:https://doi.org/10.1016/j.jip.2009.06.011.

vanEngelsdorp, D., Lengerich, E., Spleen, A., Dainat, B., Cresswell, J., et al. (2013) Standard epidemiological methods to understand and improve Apis mellifera health, in: Dietemann, V., Ellis, J. D., Neumann, P. (Eds.) The Coloss Beebook: Volume II: Standard methods for Apis mellifera pest and pathogen research. J. Apic. Res. 52 (4), 1-16. DOI:https://doi.org/10.3896 /IBRA.1.52.4.15.

Vinhal-Silva, N., Cunha, S.A., Sousa, P.O., Vitena, T.M.S., Rizzardo, R.A.G. (2018) Infestação de abelhas melíferas por varroa na Amazônia Legal, in: Anais do Congresso Brasileiro de Apicultura, 22... CBA, Joinville, SC, p. 201. Available at: http://www. conbrapi2018.com.br. Accessed 16 July 2018.

Publisher's note Springer Nature remains neutral with regard to jurisdictional claims in published maps and institutional affiliations. 